\title{
Hygienic Behavior of Apis mellifera and Its Relationship with Varroa destructor Infestation and Honey Production in the Central Highlands of Ecuador
}

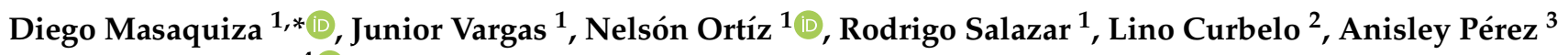 \\ and Amilcar Arenal ${ }^{4}$ (D) \\ 1 Sede Orellana, Escuela Superior Politécnica de Chimborazo, El Coca 220150, Ecuador; \\ junior.vargas@espoch.edu.ec (J.V.); nelson.ortiz@espoch.edu.ec (N.O.); rodrigo.salazar@espoch.edu.ec (R.S.) \\ 2 Centro de Estudios para el Desarrollo de la Producción Animal, Universidad de Camagüey “Ignacio \\ Agramonte Loynaz", Camagüey 74650, Camagüey, Cuba; lino.curbelo@reduc.edu.cu \\ 3 Facultad de Ciencias Agropecuarias, Fructuoso Rodríguez Pérez, Universidad de la Habana, \\ San José de las Lajas 32700, Mayabeque, Cuba; anisley.perez@unah.edu.cu \\ 4 Centro de Biología Molecular, Universidad de Camagüey "Ignacio Agramonte Loynaz”, Camagüey 74650, \\ Camagüey, Cuba; amilcar.arenal@reduc.edu.cu \\ * Correspondence: dmasaquiza@espoch.edu.ec; Tel.: +593-983135089
}

\section{check for} updates

Citation: Masaquiza, D.; Vargas, J.; Ortíz, N.; Salazar, R.; Curbelo, L.; Pérez, A.; Arenal, A. Hygienic Behavior of Apis mellifera and Its Relationship with Varroa destructor Infestation and Honey Production in the Central Highlands of Ecuador. Insects 2021, 12, 966. https://doi.org /10.3390/insects12110966

Academic Editor: Mariano Higes Pascual

Received: 30 August 2021

Accepted: 18 October 2021

Published: 25 October 2021

Publisher's Note: MDPI stays neutral with regard to jurisdictional claims in published maps and institutional affiliations.

Copyright: (c) 2021 by the authors. Licensee MDPI, Basel, Switzerland. This article is an open access article distributed under the terms and conditions of the Creative Commons Attribution (CC BY) license (https:// creativecommons.org/licenses/by/ $4.0 /)$.
Simple Summary: The honey bee (Apis mellifera) is an insect that has a relevant role in natural and agricultural ecosystems due to its leading role in the pollination of crops that are part of humanity's food chain. Even in the face of the modernization and the intensification of agriculture, the honey bee has maintained its economic importance due to the value generated by its products. At present, when attempting to improve the characteristics of bees, it is important to evaluate variables such as hygienic behavior, Varroa infestation rates, and honey production as a basis for improvement plans in search of increasing productive yields at altitudes $2600 \mathrm{~m}$ above sea level (m.a.s.l.). The strength of bees against parasites, and therefore the better development of their colonies, was determined, resulting in a healthy colony with an increase in honey production. The altitude and the hygienic behavior of bees in the central highlands showed an inverse relationship. There was no relationship between infestation rates and production; it is proposed that environmental factors do not modulate Varroa levels or honey production.

Abstract: The aim of this research was to analyze the relationship among hygienic behavior (HB), Varroa destructor infestation, and honey production in the central highlands of Ecuador. Overall, 75 honey bee colonies were evaluated before, during, and after production at three altitude levels (2600-2800, 2801-3000, and >3000 m.a.s.1.). The hygienic behavior percentage of the colonies was determined by the pin-killing method, and the colonies were classified into three groups: high HB $(>85 \%)$, mid HB $(60.1-85 \%)$, and low $\mathrm{HB}(\leq 60 \%)$. Varroa infestation was diagnosed as well, and honey production was evaluated only during production. HB was high and heterogeneous, averaging $80 \%$ $\pm 9.7 \%$. Its highest expression was observed at lower altitudes. The infestation degree was low $(3.47 \%$ $\pm 1.56 \%$ ), although the mite was detected in all colonies upon sampling. A negative correlation was observed between HB and Varroa infestation in the first sampling $\left(-0.49^{* *}\right)$, suggesting that the highand mid-altitude $\mathrm{HB}$ colonies underwent the lowest infestation rates, regardless of sampling. The correlations between $\mathrm{HB}$ and production were significant $\left(0.26^{*}\right)$, indicating a positive effect of $\mathrm{HB}$ on production, meaning that colonies with high $\mathrm{HB}$ obtained the highest honey production $(25.08 \pm$ $4.82 \mathrm{~kg} /$ hive). The HB of bees showed an inverse relationship with altitude and it tended to reduce the effect of Varroa infestation, favoring honey production and, thus, suggesting the feasibility of selecting colonies with high HB.

Keywords: hygienic behavior; Apis mellifera; Varroa destructor; infestation rates; production; honey 


\section{Introduction}

Today, honey bees are threatened by multiple factors such as the application of crop pesticides, fragmentation and loss of habitats, and the presence of pathogens and parasites [1-3]. Lately, the most disturbing factor is the presence of the mite Varroa destructor, which is the main threat to apiculture in the region [4]. This problem is also present worldwide [5-7]. This parasite drastically reduces the production of honey and other bee products [8].

Vaziritabar et al. [9] indicated that environmental conditions affect mite population development. However, it is more likely that this is observed through the indirect effect of environmental factors that regulate the numbers of bee brood or the activity of certain host defense behaviors [10].

Internationally, chemical control is the most widely used method. However, it can lead to the development of acaricide-resistant mites, raise production costs, cause toxic effects on bees and man, and contaminating hive products, making it difficult for its commercialization [11]. At present, other forms of the fight against the parasite are being developed based on the ability of bees to develop their defense mechanisms for survival.

Among them is hygienic behavior [12], wich in several studies was found to allow maintaining infestation rates at viable levels with the development and production of colonies [13]. High hygiene values in apiaries lie in the health and economic importance that this behavior represents for the colonies. This translates into healthier, more productive colonies, with greater pollinating action on crops [14]. Some populations of A. mellifera show mechanisms that allow these bee populations to coexist with the mite for longer periods without requiring any acaricidal treatment in the hive [15]. The hygienic behavior (HB) in the honey bee (A. mellifera) is the ability that workers have to detect [16], uncap, and remove diseased offspring (dead or parasitized) from inside the cells of a honeycomb from the brood chamber to the outside of the colony $[9,17]$.

The mechanisms used for the breeding selection programs are the HB, the low attractiveness of the brood, the suppression of the reproduction of the mite, and the hygienic sensitivity to varroa [18]. HB is a heritable genetic trait and high enough $(>0.5)$ to be taken into account in A. mellifera breeding programs to improve the vitality of the strains [19]. $\mathrm{HB}$ is evaluated by several methods, including removing the offspring infested with $V$. destructor [9]. Freezing with liquid nitrogen a section of the comb with the capped brood [20], and using the sacrifice of the pupae by puncture with a needle or pin [21,22]. The latter is recommended in Europe as a standard in selection programs since it shows a positive correlation with the elimination of varroa-infested pupae [15].

The importance of the hygienic behavior of honey bee colonies in association with parasite control and the bacterial and mycotic diseases of the brood is well known [23]. The mite (Varroa destructor) infested adult honey bees are found with malformed or flawed and stunted with deformed wings. The bees will uncap and cannibalize the pupae, which indicates progressed mite damage of chewed down brood [24]. The parasite destroys the mechanical protective barriers of the integument and impairs the immune system of the bees. Paray and Gupta, in 2017 [25], indicated that the benefit-cost ratio decreases with an increase in the level of Varroa mite infestation. However, the relationship of hygienic behavior with honey production remains unclear.

Studies of bee infestation by Varroa at altitudes above 2800 m.a.s.l. are scarce. Therefore, the impact of the parasite on the bee above 2800 m.a.s.l. and the interaction with bees is unknown. In that sense, this paper aimed to evaluate the hygienic behavior of honey bees (Apis mellifera) and its relationship with Varroa destructor infestation and honey production at different altitudes in the Ecuadoran highlands.

\section{Materials and Methods}

This research was conducted in 2017. The territory presents the particularity of being traversed from north to south by the mountainous system of the Andes. The climate of the center area of Ecuador classifies as a temperate semi-wet to humid. It is warm and dry 
in the valleys and high cold mountain on the paramos, over $3400 \mathrm{~m}$ above sea level. The temperature is linked to height (i.e., between 1500 and 3000 m.a.s.l.). The average values vary between 8 and $20^{\circ} \mathrm{C}$, with a temperature gradient of less than $5^{\circ} \mathrm{C}$ for every $1000 \mathrm{~m}$ high. The altitude also influences the amount of rain that precipitates because the cold air has little capacity to retain moisture so that few rainfalls occur. However, there are two defined stations: wet or winter (October to May) and dry or summer (June to September). The average rainfall varies between 800 and $1500 \mathrm{~mm} /$ year [26]

Overall, 15 apiaries (75 colonies) were studied in the provinces of Tungurahua and Chimborazo (Table 1). Samples were collected in March-April (before honey production), May-July (during production), and August-September (after production).

Table 1. Location of the studied apiaries in the Ecuadoran highlands.

\begin{tabular}{ccccc}
\hline Apiary & Location & Latitude & Longitude & Height (m.a.s.1.) \\
\hline A1 & Tungurahua & $1^{\circ} 16^{\prime} 06^{\prime \prime} \mathrm{S}$ & $78^{\circ} 34^{\prime} 50^{\prime \prime} \mathrm{W}$ & 2607 \\
A2 & Tungurahua & $1^{\circ} 22^{\prime} 09^{\prime \prime} \mathrm{S}$ & $78^{\circ} 36^{\prime} 19^{\prime \prime} \mathrm{W}$ & 2879 \\
A3 & Tungurahua & $1^{\circ} 18^{\prime} 16^{\prime \prime} \mathrm{S}$ & $78^{\circ} 39^{\prime} 16^{\prime \prime} \mathrm{W}$ & 2936 \\
A4 & Tungurahua & $1^{\circ} 19^{\prime} 02^{\prime \prime} \mathrm{S}$ & $78^{\circ} 39^{\prime} 16^{\prime \prime} \mathrm{W}$ & 3047 \\
A5 & Tungurahua & $1^{\circ} 35^{\prime} 17.37^{\prime \prime} \mathrm{S}$ & $78^{\circ} 46^{\prime} 05.25^{\prime \prime} \mathrm{W}$ & 3279 \\
A6 & Tungurahua & $1^{\circ} 33^{\prime} 11.2^{\prime \prime} \mathrm{S}$ & $78^{\circ} 42^{\prime} 32.4^{\prime \prime} \mathrm{W}$ & 3168 \\
A7 & Chimborazo & $1^{\circ} 41^{\prime} 45.57^{\prime \prime} \mathrm{S}$ & $78^{\circ} 45^{\prime} 16.46^{\prime \prime} \mathrm{W}$ & 2939 \\
A8 & Chimborazo & $1^{\circ} 39^{\prime} 26.17^{\prime \prime} \mathrm{S}$ & $78^{\circ} 34^{\prime} 38.49^{\prime \prime} \mathrm{W}$ & 2727 \\
A9 & Chimborazo & $1^{\circ} 42^{\prime} 46.63^{\prime \prime} \mathrm{S}$ & $78^{\circ} 39^{\prime} 50.33^{\prime \prime} \mathrm{W}$ & 2967 \\
A10 & Chimborazo & $1^{\circ} 35^{\prime} 11^{\prime \prime} \mathrm{S}$ & $78^{\circ} 45^{\prime} 09^{\prime \prime} \mathrm{W}$ & 3205 \\
A11 & Chimborazo & $1^{\circ} 35^{\prime} 18^{\prime \prime} \mathrm{S}$ & $78^{\circ} 46^{\prime} 03^{\prime \prime} \mathrm{W}$ & 3262 \\
A12 & Chimborazo & $1^{\circ} 41^{\prime} 34^{\prime \prime} \mathrm{S}$ & $78^{\circ} 40^{\prime} 11^{\prime \prime} \mathrm{W}$ & 2834 \\
A13 & Chimborazo & $1^{\circ} 35^{\prime} 46.75^{\prime \prime} \mathrm{S}$ & $78^{\circ} 39^{\prime} 51.45^{\prime \prime} \mathrm{W}$ & 2870 \\
A14 & Chimborazo & $1^{\circ} 43^{\prime} 46.5^{\prime \prime} \mathrm{S}$ & $78^{\circ} 36^{\prime} 47.6^{\prime \prime} \mathrm{W}$ & 2616 \\
A15 & Chimborazo & $1^{\circ} 46^{\prime} 40.91^{\prime \prime} \mathrm{S}$ & $78^{\circ} 35^{\prime} 10.99^{\prime \prime} \mathrm{W}$ & 2863 \\
\hline
\end{tabular}

m.a.s.l. meters above sea level.

\subsection{Criteria for Inclusion and Exclusion of Apiaries and Hives}

According to the characterization of beekeepers [27], inclusion and exclusion criteria were considered to locate apiaries that met the requirements to enter the investigation.

Inclusion criteria were as follows:

- Apiaries with Langstroth hives;

- Good strength of the selected colonies (seven combs covered with bees that contained an average of three breeding combs each, which is considered good strength according to [9]);

- Honey production per hive above the national average $(10.2 \mathrm{~kg})$ [28];

- No application of varroa treatment before the study;

- No introduction of queens in recent years.

Exclusion criteria were as follows:

- Swarm hives (exploration every 15 days);

- Transhumance of the apiary;

- Refusal of the beekeeper to participate in the study.

In this case, from eighteen apiaries at the study beginning, three were excluded: two from the province of Tungurahua (for swarming and transhumance) and one from Chimborazo (refusal of the beekeeper). The hives under study had a breeding chamber and two half honey supers. In addition, work was carried out during the same period (March-September), and the hives under evaluation were the same in all three samples and for all experiments. 


\subsection{Sample Collection, Analysis, and Evaluation}

The hygienic behavior, infestation rate of Varroa, and yields of all 75 colonies (six apiaries from Tungurahua and nine from Chimborazo) were determined. The methodology used in each case is presented below.

\subsubsection{Hygienic Behavior (HB)}

The evaluation was made in each colony; we chose two brooded combs containing sixteen to seventeen-day-old pupae (pink-eye pupae). We selected a ten $\times$ ten cell region, and the pupae were pin-killed. The comb was returned to the colony for evaluation after $24 \mathrm{~h}$ [22]. The total hygienic behavior (THB) formula was recorded using the formula [29].

$$
\mathrm{THB}=\frac{\text { Number of pupae removed }}{\text { total number of pierced cells }} \times 100
$$

The three HB evaluations were averaged and classified [30] with slight modifications. Colonies uncapped and removed with more than $85 \%$ of sacrificed breeding were classified as high $\mathrm{HB}$, while those removed with $60.1 \%$ to $85 \%$ of breeding as mid, and those removed with less than or equal to $60 \%$ of breeding as low.

\subsubsection{Infestation Rates (IR)}

A total of 150-200 honey bees were removed from the center of the brooding chamber and placed in a container with water and commercial detergent [31]. The mites detached from the honey bee bodies were placed on white trays and quantified. The infestation rate was determined by the formula:

$$
\mathrm{IR}=\frac{\text { Number of varroas mites }}{\text { Number of bees }} \times 100
$$

\subsubsection{Honey Production}

Each colony was weighed before and after harvest. The weight difference was considered honey yield [32]. The honey collected throughout the season was considered total honey production. The honey stored in the brooding chambers was not included.

\subsection{Statistical Analyses}

SPSS 21 was used for statistical analysis, and Kolmogorov normality tests were performed. Data are expressed as mean \pm SEM. HB data were transformed using arcsin sqr (THB/100) to meet normality. Bivariate correlations (Pearson) were as follows: THB between samples, THB and altitude level, THB and IR, and THB and production. One-way ANOVA was performed and followed by a comparison of means (Bonferroni). Bivariate correlations (Spearman) were performed for the data without normal distribution for the IR as a function of altitude level, IR as a function of production, and production as a function of altitude level. Nonparametric tests were applied for two independent samples (Mann Whitney) to compare HB, IR, and honey production.

\section{Results}

\subsection{Hygienic Behavior}

The evaluation of mean hygienic behavior in apiaries revealed it to be $80 \pm 9.7 \%$, while sampling results indicated mean values of $76.31 \%, 83.81 \%$, and $79 \%$ for the first, second, and third samplings, respectively. According to these criteria, the $\mathrm{HB}$ of all the colonies in the study could be classified as medium.

Altitude influenced the differences in the observed amount of hygienic behavior, whereby correlating the THB with different heights showed a negative result $(r=-0.25 *$; $p<0.05$ ) with the THAB of the third sampling. The results of the correlation between samples may indicate that the evaluation of the HB in the before-production stage (MarchApril) can be used as indicative of the $\mathrm{HB}$ colonies during the year in the region. Higher 
hygiene-behavior values were present at the lowest altitude, with the difference having $p<0.05$ (Table 2; Table S1).

Table 2. Evaluation of the average hygienic behavior of Apis mellifera at different altitude levels of the central highlands of Ecuador.

\begin{tabular}{|c|c|c|c|}
\hline \multirow{2}{*}{$\begin{array}{c}\text { Total Hygienic } \\
\text { Behavior (THB \%) }\end{array}$} & \multicolumn{3}{|c|}{ Altitude Levels (m.a.s.1.) } \\
\hline & $2600-2800$ & $2801-3000$ & $>3000$ \\
\hline$N$ & 15 & 35 & 25 \\
\hline Mean & $86.5^{\mathrm{a}}$ & $77.9^{b}$ & $78.9^{b}$ \\
\hline SEM & 10.29 & 8.38 & 8.34 \\
\hline Minimum & 55.3 & 51.3 & 59.7 \\
\hline Maximum & 96.7 & 90.7 & 93 \\
\hline
\end{tabular}

Different letters denote significant differences between altitude levels. m.a.s.l. meters above sea level.

Moreover, positive correlations were observed between the hygiene-behavior percentages in the first and second samplings $\left(r=0.34^{* *}\right)$, as well as between the middle and third samplings $\left(r=0.54^{* *}\right)$, among the hygiene-behavior percentages $(p<0.005)$ of all three samplings.

In the second sampling, the highest hygiene-behavior percentages were observed at the first tier, showing differences $(p<0.05)$ with the second and third tiers. In the third sampling, the colonies from the third tier showed a lower HB compared to the first tier (Figure 1; Table S1).

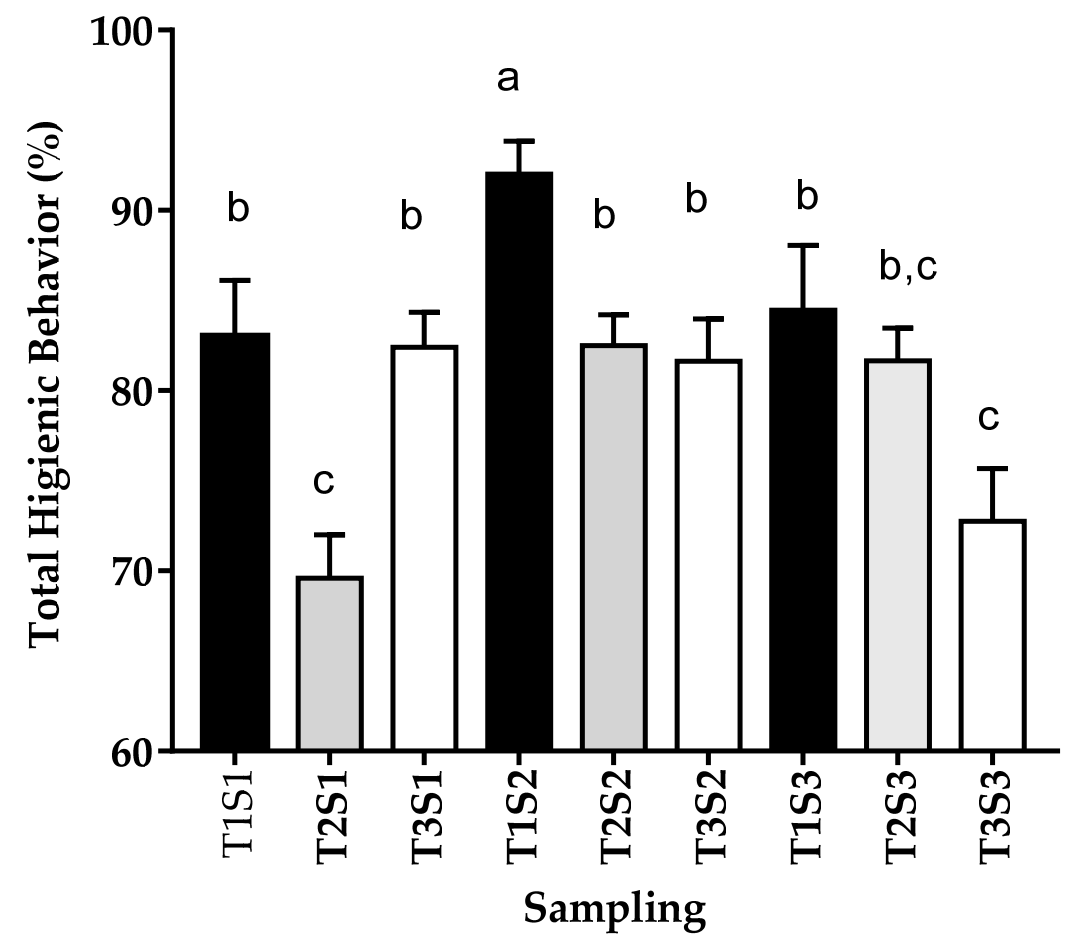

Figure 1. Hygienic behavior in each period of evaluation of colonies as a function of the different altitude levels of the central highlands of Ecuador. Samples were collected in March-April (before honey production, S1), May-July (during production, S2), and August-September (after production, S3). The data were divided into three altitude tiers 2600-2800 [T1], 2801-3000 [T2] and higher than 3000 [T3] meters above sea level (m.a.s.l). Data represent means \pm SEM (hives/sampling: T1 $n=15$, $\mathrm{T} 2 n=35, \mathrm{~T} 3 n=25)$. Different letters denote significant differences between the groups (Bonferroni).

This difference may be attributed, among factors, to the different stages undergone by the colonies during the samplings (before, during, and after production), as well as environmental changes taking place throughout the year. 


\subsection{Evaluation of Infestation Rates}

In the investigation, it was determined that varroasis was present throughout the study area. We observed an increase in colonies infested by Varroa with the progress of the honey production moment (90.7\% before, $94.7 \%$ during, and $100 \%$ at the end). Accordingly, we must also consider changes in the behavior of the parasite throughout the year, as determined by environmental conditions.

The mean infestation rate of the three samples was $3.47 \pm 1.56 \%$, with a maximum value of $12 \%$. During these evaluation periods, variability was present in the IR of $3.5 \%$, $2.6 \%$, and $4.3 \%$ for the first, second, and third samplings, respectively, showing the lowest IR during the production stage. However, throughout the production stages, the IRs were similar throughout the study area (Figure 2; Table S1). At the beginning of the period, a negative correlation $(r=-0.28 *)$ between altitude and IR was found.

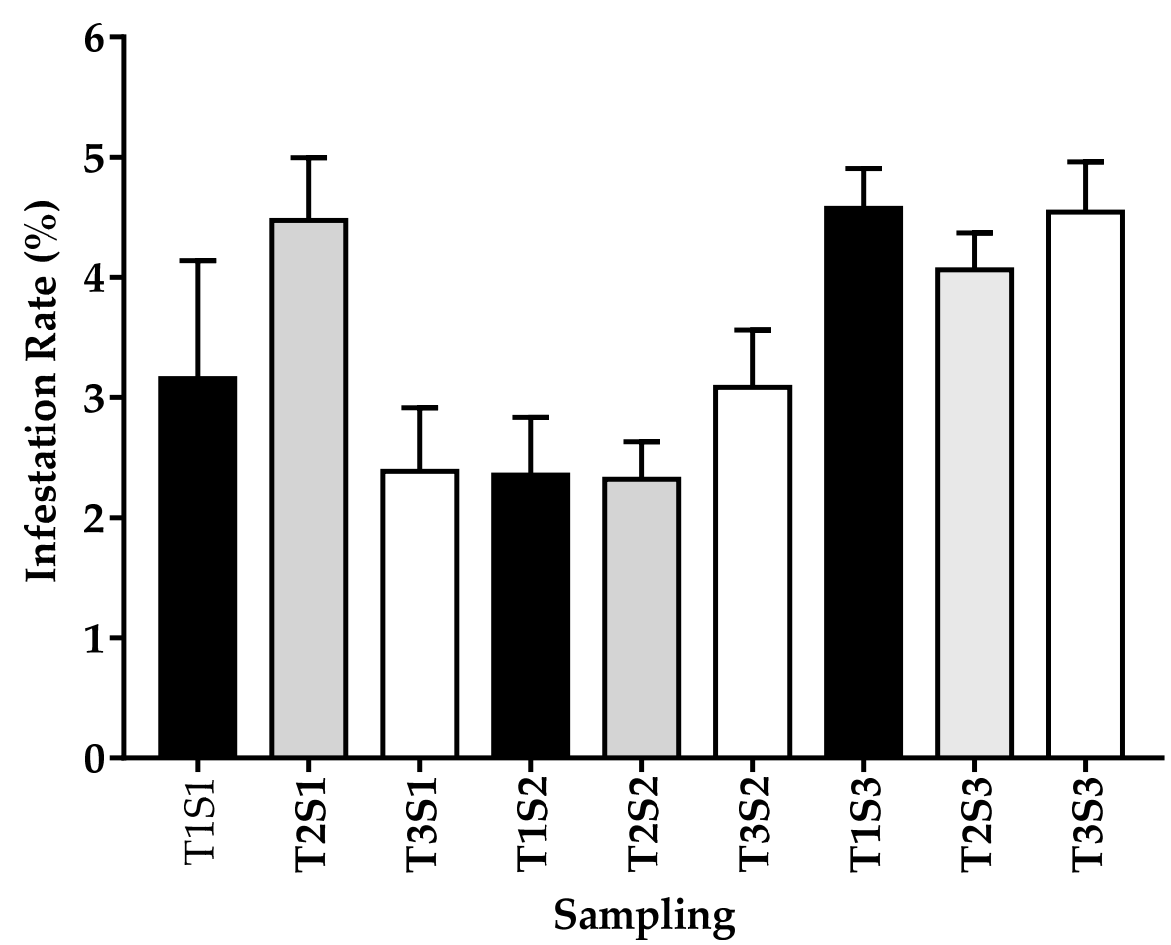

Figure 2. Infestation by Varroa destructor in each evaluation period and at different altitude tiers in the central highlands of Ecuador. Samples were collected in March-April (before honey production, S1), May-July (during production, S2), and August-September (after production, S3). The data was divided into three altitude tiers 2600-2800 [T1], 2801-3000 [T2] and higher than 3000 [T3] meters above sea level (m.a.s.l). Data represent means \pm SEM (hives/sampling: T1 $n=15$, T2 $n=35$, T3 $n=25)$. ANOVA analysis indicated lack of significant differences between groups.

Likewise, in March and April, average rates of 3.34\% (12\% maximum) were observed, which might have been caused by the better state of the colonies in that period in terms of population, with a large number of drones (which are more appealing to mites), as well as due to massive births prior to production.

\subsection{Honey Production Evaluation}

A mean production of honey of $25.08 \pm 4.82 \mathrm{~kg}$ was identified, with no relationships $(r=0.07)$ or differences $(p=0.576)$ at the different altitudes.

\subsection{Relationship between Variables: Hygienic Behavior, Infestation Rates, and Honey Production}

A negative correlation was observed between $\mathrm{HB}$ and the infestation rate in the first sampling $\left(-0.49^{* *}\right)$, contrary to the second and third samplings $(r=0.11$ and $r=-0.12$, respectively). Nonetheless, when comparing the IR based on the classified HB, the average 
total IR is $2.62 \%$ in colonies with high $\mathrm{HB}, 3.6 \%$ in colonies with mid $\mathrm{HB}$, and $8.22 \%$ in colonies with low HB (Figure 3; Table S1), indicating that the colonies with a higher HB underwent lower parasitic burdens.

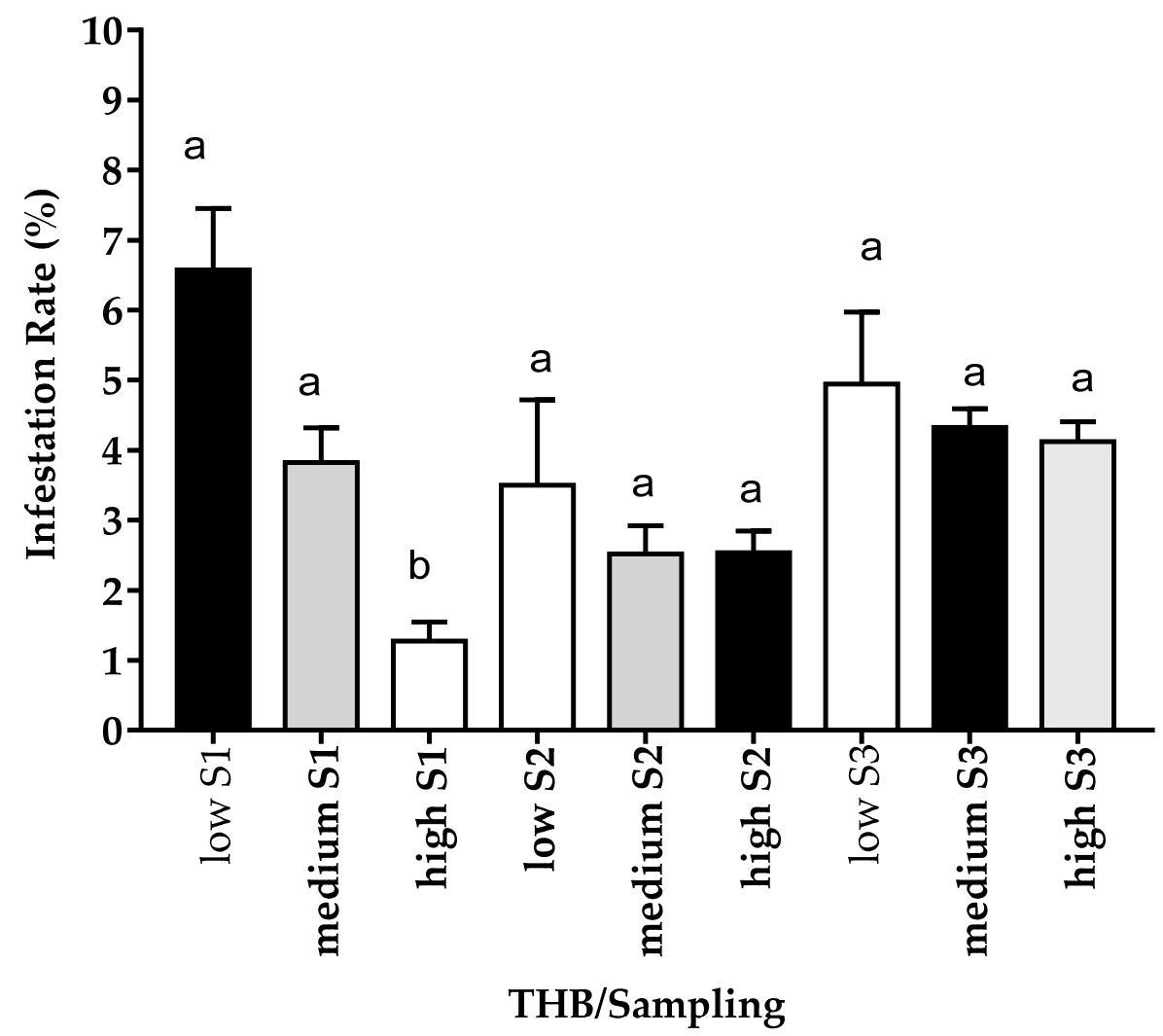

Figure 3. Varroa destructor infestation in relation to hygienic behavior (THB) (low $[<=60, n=11]$, medium [60.1-85, $n=43]$, or high [ $>85, n=21]$ ), in each evaluation period in the central highlands of Ecuador. Samples were collected in March-April (before honey production, S1), May-July (during production, S2), and August-September (after production, S3). Data represent means \pm SEM. Different letters denote significant differences between groups (Student-Newman-Keuls).

Differences in IR were identified in the three samples wherein colonies with high and mid HB had the lowest IR. The honey bees studied were not subjected to any mite-control method in the months preceding the samplings. However, the IRs were low $(3.4 \%)$, thus suggesting a process of adaptation to Varroa destructor in the local honey bees. Although the HB presented negative correlations with altitude and IR for $V$. destructor, there was no relationship between the latter two.

The larger production levels $(26.46 \mathrm{~kg} /$ colony $)$ were detected in the colonies with the higher THB. The lower levels $(23.43 \mathrm{~kg} /$ colony) were observed in colonies with intermediate $\mathrm{THB}$, with $12.9 \%$ more honey in the former.

\section{Discussion}

In the current study, the hygienic behavior values were high (80\%). In the Ecuadoran highlands, the farmers select their hives somewhat arbitrarily and there is a lack of genetic crossbreeding program. Beehives with hygienic-behavior values ranging from $80-90 \%$ can be considered high HB [33]. Colonies with high HB removed more than 95\% of the perforated offspring, albeit at $48 \mathrm{~h}$ [30]. The hygienic-behavior percentages observed in this investigation were higher than reports in Chile (20-80\%) [34] and Peru (71.75\%) [35]. However, they were lower than the values reported in Cuba, where an average of $90 \%$ of removal of dead broods was identified [29]. In Mexico, colonies with values higher than $86 \%$ HB were identified [36]. 
In addition, the importance of $\mathrm{HB}$ and its relationship with the health and production of honey bee colonies is underappreciated in Ecuador. This is in contrast to other countries, such as Cuba, Mexico, and Peru, where colonies with high hygienic behavior, low infestation, and production above the mean are subjected to selection processes.

The importance of maintaining high levels of hygiene in the apiaries lies in the sanitary and economic significance of this behavior for the colonies, which is translated into healthier, more productive colonies with more pollinating action on crops. However, the variability in the expression of this trait depends on the aptitude or composition of the colonies. It might be due to the distribution of workers to different tasks [37]. Similarly, in evaluations conducted in two different years, a wide range of variations was attributed to seasonal changes [38].

The high hygiene percentages during the second sampling, coinciding with honey production, may be attributed to the abundant input of nectar and pollen. This stimulates the bees to clean the hives, related to the need for space to store these products in the colony [20]. Likewise, the abundant input of nectar during honey production stimulates the posture of the queen, requiring clean cells [39]. The last criteria supported the idea of conducting serial analyses of hygienic behavior throughout the year and determining their means to evaluate honey bee populations in any region.

The high prevalence of the mite may be associated with different causes, including inadequate colony management by farmers, transhumance, the uncontrolled exchange of queens and bee material, the presence of wild bees, and the absence of breeding programs in the region [40]. A lower prevalence of the mite, $88 \%$, was found in Mexico [30], whereas a study in the US found $90 \%$ prevalence [41].

These infestation rates were lower than those observed in Cuba (5.36\%) [42], as well as lower than the values of $7.51 \%$ and $6.07 \%$ obtained for father and mother lines, respectively [29]. Meanwhile, in Mexico, infestations reached 6.76\% and 6.82\% [36]. This behavior could be linked to environmental effects on mites and honey bee colonies. The presence of Africanization in the apiaries needs to be studied. Recently, a report of Ecuadoran bees demonstrated Africanization [43].

The increase in IR (average of 4.4\%) during the third sampling (August and September) could be associated with factors such as production, the decrease in bee populations, and the displacement of a greater quantity of mites toward adult bees because there is a reduction in the posture of the queen in this period, due to it being the end of the production season.

Contradictory results have been reported with respect to the positive correlation of Varroa levels with altitude [44]. At the same time, a lack of correlation between elevation and Varroa levels suggests that the mite has managed to adapt to the environmental conditions of the highlands since there were IRs with slight variations at the three altitude tiers. However, a genetic component could also influence the bees since the IRs found were lower than those found in populations of European genotype and similar to those of African origin $[45,46]$.

Factors, such as the existence of other pathogens, may promote the presence and spread of Varroa [47]. These may include temperature and humidity, soil use, pesticide burden, and the availability of resources [40]. Nevertheless, the infestation levels observed in this study were within a nonlethal range for the colonies [48]. However, low Varroa infestation may lead to the appearance of diseases following subsequent declines in the yield of honey [49].

The lack of evidence for differences in honey production at different altitudes may be attributed to the evaluation taking place during the period with the highest nectar flow in the region. The principal nectar source is eucalyptus (Eucaliptus globulus Labill.) [27]. In addition, it is indicated that the abundance and type of flowering constitute the main factor determining production [44]. However, factors related to colony management can significantly impact honey production. 
Similar results were found in Mexico, with a mean production of $27.5 \mathrm{~kg}$ in the fall and $21.6 \mathrm{~kg}$ in the spring for colonies with high $\mathrm{HB}$, and a mean yield of 21.42 and $13.45 \mathrm{~kg}$, respectively, for those with low $\mathrm{HB}$, at altitudes below 1400 m.a.s.l. [48]. Honey production depends on the interaction of factors such as the size of the population, the continuous work of honey bees, and the environment [50]. The influence of the locality brings variability in the expression of behavioral traits, IR, and production, which can be interpreted as the sum of all abiotic and biotic components in a given environment [51]. In addition, different genotypes may vary in the degree to which their phenotypes are affected by specific environmental conditions [52].

In Mexico and Chile, Varroa infestation rate and hygienic behavior lack of relationship [34,53]. The effectiveness of HB in reducing IR depends on several factors as the stage of colony development, environmental conditions [54], and parasite biology [2]. Nevertheless, a study revealed that bees are dependent on self-defense or natural resistance [55]. $\mathrm{HB}$ is important for determining the general tolerance and resistance of bees to pests and diseases [56].

The honey bees studied in tropical areas, such as Cuba [29], showed higher HB than the findings of this research. However, the IRs were also higher, indicating the possibility of high hygienic aptitude for cleansing but without the capacity to detect Varroa in brooding cells as in Africanized bees. These results suggest that colonies of Africanized-honey bee descendants are less prone to Varroa infestations than European honey bee colonies in a variety of scenarios. However, it is suggested that quantitative differences in colony-level hygienic performance are due to the different percentages of workers dedicated to hygienic behaviors, since the number of such bees is tripled in colonies with high HB.

A study in Mexico detected no differences in V. destructor infestation levels between colonies with high and low HB [30]. In Brazil, high heterogeneity was found when evaluating HB and IR in Africanized honey bees [57]. However, previous results suggest that the largely hygienic colonies were more prone to having a disperse or irregular pattern of capped or uncapped cells due to their ability to detect and remove Varroa [58]. Similar data were found when studying Africanized honey bees (3-4\%) and bees in the United States (3.3-5.1\%) [59]. In addition, a study on populations of $A$. $m$. scutellata in South Africa revealed that the presence of Varroa mites was common, despite BIR never exceeding $4 \%$ [60].

In turn, it has been reported that the European honey bee colonies in Europe, Asia, and North America have undergone massive losses, compared to honey bees from other parts of the world, which have successfully survived the pathogen [61]. In Brazil, the hybrids of Africanized honey bees have shown distinct behaviors, with some resistance and tolerance to mites [62]. These individuals have high genetic identification with their African ancestor and, thus, their genotypic qualities are different from those of European bees [63]. Some behavioral traits in bees are not learned but inherited, as in the case of HB [38].

This study support the findings related to the tolerance that $\mathrm{HB}$ offers to the colonies toward the parasite, due to its high heritability $(h 2=0.65)$ being transmitted to other generations even if environmental conditions are different from those of its predecessors [64], as identified at the different altitude tiers in the central highlands of Ecuador. However, previous results indicated a positive correlation between the altitude and the number of adults of $V$. destructor $[44,65]$. Contradictorily, a higher number of mites was determined with increasing altitude, suggesting that environmental factors, such as temperature and humidity, could modify the host's behavior but not the mite's, since the $V$. destructor lacks stages of free life [66].

Likewise, a high correlation $(r=0.73)$ was found in Africanized bees between the variables [67], as well as in European bees $\left(r=0.17^{*}\right)$ [51]. Similar results were found in colonies with high $\mathrm{HB}$, which produced $23 \%$ more honey than the colonies with low $\mathrm{HB}$. The differences in production may be because colonies with high HB eliminate diseases and 
parasites more quickly $[17,36]$. Thus, the harmful effects of the mite are minimal, which allows superior honey production [68].

In general, the results of this work suggest that selection is possible both for a higher $\mathrm{HB}$ and for higher honey production. However, this does not mean that these traits are genetically linked [23]. We detected a lack of correlation between IR and honey production; although it should be noted that mite infestation levels were low, and productive yields were acceptable. This parasite can seriously affect the production of honey when IRs are greater than $5 \%[69,70]$.

Equally, it was demonstrated that there are reductions in honey production with $1 \%$ infestation, worsening with an increase in infestation as a function of the area, the weather, and other factors involved in honey production [25]. The scientific literature provides conflicting results with those of the present investigation considering the effect of Varroa infestation on honey production. Varroa destructor infestation affects the quality of lipid, protein, and honey production [71]. In addition, the lack of a relationship between IR and honey production does not mean that Varroa destructor is absent in the colonies. On the other hand, thanks to their defense mechanisms, the bees can tolerate its effects due to low infestations in the colonies.

\section{Conclusions}

Varroa destructor infestation rates and honey production are unrelated to altitude in the central highlands of Ecuador, suggesting that highland environmental conditions do not modulate Varroa levels or production.

The hygienic behavior of bees in the central highlands of Ecuador shows an inverse relationship with altitude. It reduces the effect of Varroa infestation, favoring honey production and suggesting the feasibility of selecting colonies with high HB.

Supplementary Materials: The following are available online at https:/ / www.mdpi.com/article/10 .3390 /insects12110966/s1, Table S1: sampling results.

Author Contributions: Conceptualization, D.M., L.C. and A.A.; methodology, D.M. and A.A.; software, A.A.; validation, L.C., A.P. and A.A.; formal analysis, D.M., J.V., R.S. and N.O.; investigation, D.M.; resources, D.M.; data curation, D.M., L.C., A.A., R.S. and A.P.; writing—original draft preparation, D.M. and J.V.; writing-review and editing, D.M. and N.O.; supervision, A.A., L.C. and A.P.; project administration, A.A. and L.C. All authors have read and agreed to the published version of the manuscript.

Funding: This research received no external funding.

Institutional Review Board Statement: Not applicable.

Informed Consent Statement: Not applicable.

Data Availability Statement: The data presented in this study are available in Supplementary Materials.

Conflicts of Interest: The authors declare no conflict of interest.

\section{References}

1. Antúnez, K.; Martín-Hernández, R.; Prieto, L.; Meana, A.; Zunino, P.; Higes, M. Immune suppression in the honey bee (Apis mellifera) following infection by Nosema ceranae (Microsporidia). Environ. Microbiol. 2009, 11, 2284-2290. [CrossRef]

2. Rosenkranz, P.; Aumeier, P.; Ziegelmann, B. Biology and control of Varroa destructor. J. Invertebr. Pathol. 2010, 103, S96-S119. [CrossRef] [PubMed]

3. Sánchez-Bayo, F.; Goulson, D.; Pennacchio, F.; Nazzi, F.; Goka, K.; Desneux, N. Are bee diseases linked to pesticides?-A brief review. Environ. Int. 2016, 89-90,7-11. [CrossRef]

4. Giménez, P.; Mendoza, Y.; Invenizzi, C.; Fuselli, S.; Alonso, R.; Fernández, P.; Maggi, M. Morphometric correlation between Apis mellifera morphotypes (Hymenoptera) and Varroa destructor (Acari) from Uruguay. J. Apic. Res. 2017, 56, 122-129. [CrossRef]

5. Smart, M.; Pettis, J.; Rice, N.; Browning, Z.; Spivak, M. Linking measures of colony and individual honey bee health to survival among apiaries exposed to varying agricultural land use. PLOS ONE 2016, 11, e0152685. [CrossRef]

6. Steinhauer, N.; Kulhanek, K.; Antúnez, K.; Human, H.; Chantawannakul, P.; Chauzat, M.-P. Drivers of colony losses. Curr. Opin. Insect Sci. 2018, 26, 142-148. [CrossRef] [PubMed] 
7. van Der Zee, R.; Gray, A.; Pisa, L.; De Rijk, T. An observational study of honey bee colony winter losses and their association with Varroa destructor, neonicotinoids and other risk factors. PLoS ONE 2015, 10, e0131611. [CrossRef] [PubMed]

8. Khongphinitbunjong, K.; de Guzman, L.; Rinderer, T.E.; Tarver, M.R.; Frake, A.M.; Chen, Y.; Chantawannakul, P. Responses of Varroa-resistant honey bees (Apis mellifera L.) to deformed wing virus. J. Asia Pac. Entomol. 2016, 19, 921-927. [CrossRef]

9. Vaziritabar, S.; Aghamirkarimi, A.; Mehdi, S. Evaluation of the defensive behavior in two honeybee races Iranian honeybee (Apis mellifera meda) and Carniolan honeybee (Apis mellifera carnica) and grooming behavior of different bee races in controlling Varroa destructor mite in honey. J. Entomol. Zool. Stud. 2016, 4, 586-602.

10. Xonis, C.; Thrasyvoulou, A.; Taj, H. Variability of hygienic behavior in bee Apis mellifera macedonica. Bulg. J. Agric. Sci. 2015, 21, 674-679.

11. Giacobino, A.; Molineri, A.; Cagnolo, N.B.; Merke, J.; Orellano, E.; Bertozzi, E.; Masciángelo, G.; Pietronave, H.; Pacini, A.; Salto, C.; et al. Risk factors associated with failures of Varroa treatments in honey bee colonies without broodless period. Apidologie 2015, 46, 573-582. [CrossRef]

12. Danka, R.G.; Harris, J.W.; Villa, J.D.; Dodds, G.E. Varying congruence of hygienic responses to Varroa destructor and freeze-killed brood amoung different types of honeybees. Apidologie 2013, 44, 447-457. [CrossRef]

13. Medina-Flores, C.; Guzmán-Novoa, E.; Aréchiga-Flores, C.; Aguilera-Soto, J.; Gutiérrez-Piña, F. Efecto del nivel de infestación de Varroa destructor sobre la producción de miel de colonias de Apis mellifera en el altiplano semiárido de México. Rev. Mex. de Cienc. Реси. 2011, 2, 313-317.

14. Buenas Prácticas Pecuarias en la Producción Primaria de Miel; SAGARPA: Ciudad de México, Mexico, 2018.

15. Strauss, U.; Dietemann, V.; Human, H.; Crewe, R.M.; Pirk, C.W. Resistance rather than tolerance explains survival of savannah honeybees (Apis mellifera scutellata) to infestation by the parasitic mite Varroa destructor. Parasitology 2016, 143, 374-387. [CrossRef]

16. Oddie, M.; Büchler, R.; Dahle, B.; Kovacic, M.; Le Conte, Y.; Locke, B.; de Miranda, J.R.; Mondet, F.; Neumann, P. Rapid parallel evolution overcomes global honey bee parasite. Sci. Rep. 2018, 8, 7704. [CrossRef]

17. Akinwande, K.; Badejo, M.; Ogbogu, S. Hygienic behavioural mechanism of resistance to diseases and parasites in west african honey bee colonies Apis mellifera adansonii (HYMENOPTERA: APIDAE). Int. J. Entomol. Res. 2014, 2, 73-79.

18. Verde, M.; Demedio, J.; Gómez, T. Apicultura, Salud y Producción: Guía Técnica para el Apicultor; Consejo Científico Veterinario de Cuba: La Habana, Cuba, 2013.

19. Lin, Z.; Page, P.; Li, L.; Qin, Y.; Zhang, Y.; Hu, F.; Neumann, P.; Zheng, H.; Dietemann, V. Go east for better honey bee health: Apis cerana is faster at hygienic behavior than A. mellifera. PLoS ONE 2016, 11, e0162647. [CrossRef] [PubMed]

20. Spivak, M.; Downey, D.L. Field assays for hygienic behavior in honey bees (Hymenoptera: Apidae). J. Econ. Entomol. 1998, 91, 64-70. [CrossRef]

21. Gramacho, K. Fatores que Interferem no Comportamento Higiênico das Abelhas Apis mellifera. Doctoral Thesis, Universidade de São Paulo, Butanta, Brazil, 1999.

22. Newton, D.; Ostasiewski, N. A simplified bioassay for behavioral resistance to american foulbrood in honey-bees. Am. Bee J. 1986, $126,278-281$.

23. Leclercq, G.; Pannebakker, B.; Gengler, N.; Nguyen, B.K.; Francis, F. Drawbacks and benefits of hygienic behavior in honey bees (Apis mellifera L.): A review. J. Apic. Res. 2017, 56, 366-375. [CrossRef]

24. Chauhan, A.; Dabhi, M.; Patnaik, R. Review on Varroa mite: An invasive threat to apiculture industry. J. Entomol. Zool. Stud. 2021, 9, 535-539.

25. Paray, M.; Gupta, S. Economic threshold of Varroa destructor (Anderson and Trueman) infesting Apis mellifera in Kashmir. Indian J. Entomol. 2017, 79, 27-31. [CrossRef]

26. Ron, S.; Merino-Viteri, A.; Ortiz, D. Anfibios del Ecuador; Version 20190; Museo de Zoología, Pontificia Universidad Católica del Ecuador: Quito, Ecuador, 2019.

27. Masaquiza-Moposita, D.A.; Llerena Hidalgo, G.O.; Díaz Monroy, B.L.; Curbelo Rodríguez, L.; Carrasco Carrasco, R.U.; Guapi Guamán, R.A. Characterization of beekeeping systems in Central Ecuadoran regions. Agrisost 2017, $23,103-111$.

28. Programa Nacional Apícola; MAGAP: Quito, Ecuador, 2017.

29. Pérez, A. Correspondencia de los Índices de Infestación por Varroa destructor y los Mecanismos Defensivos, con la Condición de Europeas y Selectas de las Colmenas en un Centro Genético de Producción de Abejas Reinas. Doctoral Thesis, Universidad Agraria de la Habana "Fructuoso Rodríguez Pérez", Habana, Cuba, 2014.

30. Medina-Flores, C.A.; Guzman-Novoa, E.; Aréchiga Flores, C.F.; Gutiérrez Bañuelos, H.; Aguilera Soto, J.I. Honey production and Varroa destructor infestation of Africanized honey bee (Apis mellifera) colonies with high and low hygienic behavior. Rev. Mex. de Cienc. Ресu. 2014, 5, 157-170.

31. De Jong, D.; Roma, D.; Goncalves, L. A comparative analysis of shaking solutions for the detection of Varroa jacobsoni on adult honeybees. Apidologie 1982, 13, 297-306. [CrossRef]

32. Büchler, R.; Andonov, S.; Bienefeld, K.; Costa, C.; Hatjina, F.; Kezic, N.; Kryger, P.; Spivak, M.; Uzunov, A.; Wilde, J. Standard methods for rearing and selection of Apis mellifera queens. J. Apic. Res. 2013, 52, 1-30. [CrossRef]

33. Gramacho, K.; Gonçalves, L.; Rosenkranz, P.; De Jong, D. Influence of body fluid from pin-killed honey bee pupae on hygienic behavior. Apidologie 1999, 30, 367-374. [CrossRef]

34. Araneda, X.; Pérez, R.; Castillo, C.; Medina, L. Evaluación del comportamiento higiénico de Apis mellifera L. en relación al nivel de infestación de Varroa destructor Anderson y Trueman. IDESIA 2008, 26, 59-67. [CrossRef] 
35. Vásquez, O.; Mestanza, B.; Alarcón, R. Características morfométricas, comportamiento higiénico y agresividad de abejas criollas Apis mellifera sp. Rev. de Investigación y Cult. 2016, 5, 16-23.

36. Contreras, D.; Pérez, M.; Payró, E.; Rodríguez, G.; Castañeda, E.; Gómez, R. Comportamiento defensivo, sanitario y producción de ecotipos de Apis mellifera L. en Tabasco, México. Rev. Mex. de Cienc. Agrícolas 2016, 7, 1867-1877. [CrossRef]

37. Scannapieco, A.; Lanzavecchia, S.; Parreño, M.; Liendo, M.; Cladera, J.; Spivak, M.; Palacio, M.A. Individual precocity, temporal persistence, and task-specialization of hygienic bees from selected colonies of Apis mellifera. J. Apic. Sci. 2016, 60, 63-74. [CrossRef]

38. Boutin, S.; Alburaki, M.; Mercier, P.-L.; Giovenazzo, P.; Derome, N. Differential gene expression between hygienic and nonhygienic honeybee (Apis mellifera L.) hives. BMC Genom. 2015, 16, 1. [CrossRef]

39. Janmaat, F.; Winston, L. Removal of Varroa jacobsoni infested brood in honey bee colonies with differing pollen stores. Apidologie 2000, 31, 377-385. [CrossRef]

40. Giacobino, A.; Bulacio, C.; Merke, J.; Orellano, E.; Bertozzi, E.; Masciangelo, G.; Pietronave, H.; Salto, C.; Signorini, M. Risk factors associated with the presence of Varroa destructor in honey bee colonies from east-central Argentina. Prev. Vet. Med. 2014, 115, 280-287. [CrossRef]

41. Rose, R.; Pettis, J.; Rennich, K.; van Engelsdorp, D. Estudio Nacional de las Plagas y Enfermedades de la Abeja Melifera en Estados Unidos; USDA: Washington, DC, USA, 2014.

42. Sanabria, J.; Demedio, J.; Pérez, T.; Peñate, I.; Rodríguez, D.; Lóriga, W. Índices de infestación por Varroa destructor en colmenas sin medidas de control. Rev. de Salud Anim. 2015, 37, 118-124.

43. Acosta, J. Caracterización Morfométrica y Molecular de Apis mellifera Provenientes de Colmenas Localizadas en las Provincias de Pichincha, Imbabura y Carchi-Ecuador. Engineering Thesis, Universidad de las Fuerzas Armadas ESPE, Quito, Ecuador, 2018.

44. Muli, E.; Patch, H.; Frazier, M.; Frazier, J.; Torto, B.; Baumgarten, T.; Kilonzo, J.; Ng'ang'a Kimani, J.; Mumoki, F.; Masiga, D.; et al. Evaluation of the distribution and impacts of parasites, pathogens, and pesticides on honey bee (Apis mellifera) populations in East Africa. PLoS ONE 2014, 9, e94459. [CrossRef]

45. Martin, S.J.; Medina, L.M. Africanized honeybees have unique tolerance to Varroa mites. Trends Parasitol. 2004, $20,112-114$. [CrossRef]

46. Tibatá, V.M.; Sanchez, A.; Palmer-Young, E.; Junca, H.; Solarte, V.M.; Madella, S.; Ariza, F.; Figueroa, J.; Corona, M. Africanized honey bees in Colombia exhibit high prevalence but low level of infestation of Varroa mites and low prevalence of pathogenic viruses. PLOS ONE 2021, 16, e0244906. [CrossRef]

47. Bahreini, R.; Currie, R. The influence of Nosema (Microspora: Nosematidae) infection on honey bee (Hymenoptera: Apidae) defense against Varroa destructor (Mesostigmata: Varroidae). J. Invertebr. Pathol. 2015, 132, 57-65. [CrossRef] [PubMed]

48. Medina Flores, C.A.M.; Guzmán Novoa, E.G.; Hamiduzzaman, M.; Aguilera Soto, J.I.A.; López Carlos, M.A. Africanization of honey bees (Apis mellifera) in three climatic regions of northern Mexico. Vet. México 2017, 2, 6-9. [CrossRef]

49. Martin, S.J.; Highfield, A.C.; Brettell, L.; Villalobos, E.M.; Budge, G.E.; Powell, M.; Nikaido, S.; Schroeder, D.C. Global honey bee viral landscape altered by a parasitic mite. Science 2012, 336, 1304-1306. [CrossRef] [PubMed]

50. Medina-Flores, C.; Guzmán-Novoa, E.; Aguilera, J.; López, M.; Medina, S. Condiciones poblacionales y alimenticias de colonias de abejas melíferas (Apis mellifera) en tres regiones del altiplano semiárido de México. Rev. Mex. de Cienc. Pecu. 2019, 10, 199-211. [CrossRef]

51. Uzunov, A.; Costa, C.; Panasiuk, B.; Meixner, M.; Kryger, P.; Hatjina, F.; Bouga, M.; Andonov, S.; Bienkowska, M.; Le Conte, Y.; et al. Swarming, defensive and hygienic behaviour in honey bee colonies of different genetic origin in a pan-European experiment. J. Apic. Res. 2014, 53, 248-260. [CrossRef]

52. Büchler, R.; Costa, C.; Hatjina, F.; Andonov, S.; Meixner, M.; Le Conte, Y.; Uzunoc, A.; Berg, S.; Bienkowska, M.; Bouga, M.; et al. The influence of genetic origin and its interaction with environmental effects on the survival of Apis mellifera L. colonies in Europe. J. Apic. Res. 2014, 53, 205-214. [CrossRef]

53. Mondragón, L.; Spivak, M.; Vandame, R. A multifactorial study of the resistance of honeybees Apis mellifera to the mite Varroa destructor over one year in México. Apidologie 2005, 36, 345-358. [CrossRef]

54. Hatjina, F.; Costa, C.; Büchler, R.; Uzunov, A.; Drazic, M.; Filipi, J.; Charistos, L.; Ruottinen, L.; Andonov, S.; Meixner, M.D.; et al. Population dynamics of European honey bee genotypes under different environmental conditions. J. Apic. Res. 2014, 53, $233-247$. [CrossRef]

55. Akinwande, K.; Badejo, M.; Ogbogu, S. Morphometrics and parasitic load of Varroa mites (Acari: Varroidea) on Colonies of Apis mellifera adansonii in south-west Nigeria. Acarina 2013, 21, 17-25.

56. Spivak, M.; Gilliam, M. Hygienic behaviour of honey bees and its application for control of brood diseases and Varroa: Part II. Studies on hygienic behaviour since the Rothenbuhler era. Bee World 1998, 79, 169-186. [CrossRef]

57. Pinto, F.; Puker, A.; Barreto, L. The ectoparasite mite Varroa destructor Anderson and Trueman in southeastern Brazil apiaries: Effects of the hygienic behavior of Africanized honey bees on infestation rates. Arq. Bras. de Med. Veterinária e Zootec. 2012, 64, 1194-1199. [CrossRef]

58. Frazier, M.; Caron, D.; Van Engelsdorp, D. A Field Guide to Honey Bees and Their Maladies; Pennsylvania State University: State College, PA, USA, 2011.

59. Berry, J.; Owens, W.; Delaplane, K. Small-cell comb foundation does not impede Varroa mite population growth in honey bee colonies. Apidologie 2010, 41, 40-44. [CrossRef] 
60. Strauss, U.; Human, H.; Gauthier, L.; Crewe, R.; Dietemann, V.; Pirk, C. Seasonal prevalence of pathogens and parasites in the savannah honeybee (Apis mellifera scutellata). J. Invertebr. Pathol. 2013, 114, 45-52. [CrossRef] [PubMed]

61. Coelho, F.; Santos, J.; Bliman, P. Behavioral modulation of the coexistence between Apis mellifera and Varroa destructor: A defense against colony collapse? Peer J. PrePrints 2015, 3, e1396v1.

62. Hamiduzzaman, M.; Sinia, A.; Guzmán-Novoa, E.; Goodwin, P. Entomopathogenic fungi as potential biocontrol agents of the ecto-parasitic mite, Varroa destructor, and their effect on the immune response of honey bees (Apis mellifera L.). J. Invertebr. Pathol. 2012, 111, 237-243. [CrossRef] [PubMed]

63. Scott, S.; DeGrandi-Hoffman, G.; Smith, D. The African honey bee: Factors contributing to a successful biological invasion. Annu. Rev. Entomol. 2004, 49, 351-376. [CrossRef]

64. Harbo, J.R.; Harris, J.W. Heritability in honey bees (Hymenoptera: Apidae) of characteristics associated with resistance to Varroa jacobsoni (Mesostigmata: Varroidae). J. Econ. Entomol. 1999, 92, 261-265. [CrossRef]

65. Mumbi, C.T.; Mwakatobe, A.R.; Mpinga, I.H.; Richard, A.; Machumu, R. Parasitic mite, Varroa species (Parasitiformes: Varroidae) infesting the colonies of African honeybees, Apis mellifera scutellata (Hymenoptera: Apididae) in Tanzania. J. Entomol. Zool. Stud. 2014, 2, 188-196.

66. Chemurot, M.; Brunain, M.; Akol, A.; Descamps, T.; de Graaf, D. First detection of Paenibacillus larvae the causative agent of American Foulbrood in a Ugandan honeybee colony. SpringerPlus 2016, 5, 1090. [CrossRef] [PubMed]

67. Garcia, R.; Oliveira, N.; Camargo, S.; Pires, B.; Oliveira, C.; Teixeira, R.; Pickler, M.A. Honey and propolis production, hygiene and defense behaviors of two generations of Africanized honey bees. Sci. Agric. 2013, 70, 74-81. [CrossRef]

68. Bigio, G.; Al Toufailia, H.; Ratnieks, F. Honey bee hygienic behaviour does not incur a cost via removal of healthy brood. J. Evol. Biol. 2014, 27, 226-230. [CrossRef] [PubMed]

69. Kefuss, J.; Vanpoucke, J.; Bolt, M.; Kefuss, C. Selection for resistance to Varroa destructor under commercial beekeeping conditions. J. Apic. Res. 2015, 54, 563-576. [CrossRef]

70. Namayanja, D. Infestation Levels and Control of the Varroa Mite (Varroa destructor) in Managed Honey Bee Colonies from Selected Agro Ecological Zones of Uganda; Makerere University: Kampala, Uganda, 2018.

71. Dolezal, A.G.; Carrillo-Tripp, J.; Miller, W.A.; Bonning, B.C.; Toth, A.L. Intensively cultivated landscape and varroa mite infestation are associated with reduced honey bee nutritional state. PLoS ONE 2016, 11, e0153531. [CrossRef] [PubMed] 